Otterbein University

Digital Commons @ Otterbein

\title{
"Better Than White Trash": Work Ethic, Latinidad and Whiteness in Rural Arkansas
}

Miranda Cady Hallett

Otterbein University

Follow this and additional works at: https://digitalcommons.otterbein.edu/socio_fac

Part of the Anthropology Commons, and the Sociology Commons

\section{Repository Citation}

Hallett, Miranda Cady, "'Better Than White Trash": Work Ethic, Latinidad and Whiteness in Rural Arkansas" (2012). Sociology Faculty Scholarship. 2.

https://digitalcommons.otterbein.edu/socio_fac/2

This Article is brought to you for free and open access by the Sociology at Digital Commons @ Otterbein. It has been accepted for inclusion in Sociology Faculty Scholarship by an authorized administrator of Digital Commons @ Otterbein. For more information, please contact digitalcommons07@otterbein.edu. 


\title{
Original Article
}

\section{"Better than White trash": Work ethic, Latinidad and Whiteness in rural Arkansas}

\author{
Miranda Cady Hallett \\ Otterbein University, $\mathrm{OH}$
}

\begin{abstract}
Diverse sites in the US South are being transformed by "new Latino immigration." Rather than being a homogeneous process, experiences of migrant settlement are shaped by the racialized social worlds of particular historical social communities - and may in turn transform local racial formations (Winders, 2005). In one small town in rural Arkansas, Latina and Latino migrants perform boundary work (Lamont, 2000; Hartigan, 2010), constructing their identities as "good" workers and neighbors. Although migrants assert belonging and dignity by framing themselves as "better than White trash," nonetheless this belonging is predicated on the reproduction of racial and class hierarchy as well as conformity to the structural demands of neoliberal capitalism.
\end{abstract}

Latino Studies (2012) 10, 81-106. doi:10.1057/lst.2012.14

Keywords: Salvadorans; immigration; boundary work; labor; agency; Whiteness

\section{Boundaries of Belonging, Moralities of Work}

Boundaries are normative in that they are routinely used to establish basic distinctions between good and bad people - distinctions used to determine who belongs where in social space.

\section{Matt Wray in Not Quite White 162006}


1 I utilize the term "migrant" rather than "immigrant" for two reasons. It more closely approximates the preferred term used by my informants, migrante, and it emphasizes the potential nonlinearity of movement and legal vulnerability that conditions many SalvadoranArkansans' presence in the region.

2 There are a number of factors that distinguish undocumented Central American migrants from Mexicans in a similar situation (Rodríguez, 1987, 5-6; see also Hamilton and Stoltz Chinchilla, 1991; Arias, 2003; Rodríguez, 2007). Within the Central American context, Salvadorans are perceived as "hard
Latino migration into the United States fundamentally concerns a social process of negotiation involving boundaries. Assertions regarding who "belongs" and who does not in particular local communities of settlement are always already articulated with concerns and narratives regarding the boundaries of national belonging and the integrity and security of physicalcum-cultural boundaries such as the US-Mexico border. Both at the national and local levels, such boundaries are symbolically embedded with discourses of morality and human worth; debates regarding the fitness of Latin American migrants to become American are frequently framed in terms of these migrants' moral legitimacy, a frame in which the criminalization of unauthorized status and the imagery of the vulnerable and militarized border have both played a devastating role. This article explores the fraught entanglement of Salvadoran migrants ${ }^{1}$ in processes of moral assertion and boundary construction in a site of recent Latino migrant settlement in the rural landscape of central Arkansas.

Recent work in anthropology, geography and migration studies has pointed to the segregation and social exclusion of Latin American-born residents in new destinations in the United States and emphasized the ways such exclusion naturalizes and perpetuates exploitation and legal subordination (see Bailey et al, 2002; Holmes, 2007; Nelson and Hiemstra, 2008). Other researchers have found that Latinos have achieved a measure of recognition in certain receiving communities, often sites where the labor of recent migrants is crucial to the economy (Hernández-León and Zúñiga, 2000; Grey and Woodrick, 2005; Stull and Broadway, 2008). It is impossible to consider these case studies of incorporation without considering how immigration policy, in particular the construction of "illegality," creates impossible conditions for social subjects and constructs powerful social boundaries, often racialized (Ngai, 2004; Spickard, 2007; Chávez, 2008; Motomura, 2008).

In my research in a small town in rural Arkansas, I found that an uncanny combination of inclusion and subordination prevailed: Salvadoran ${ }^{2}$ migrants are, in their own view and in the discourse of many locals, an accepted and important part of the community. At the same time, they and other Latinos are structurally contained in low-wage, low-status jobs in the poultry processing industry - an industry where working conditions have worsened even as wages stagnated over the past several decades. Legal claims for labor rights on the part of foreign-born workers are minimal, exclusion from legal status is common and political participation nonexistent. From the viewpoint of rural Arkansas, the boundary of "illegality" here is not a static racialized border enforcing the limits of national identity, but a complicated (and negotiated) social condition integrally tied to labor subordination and political exclusion.

In this article, I present a study of the simultaneous social acceptance and ethnic differentiation and subordination emergent around recent communities of Salvadoran migrants in rural Arkansas. By embracing their identities as workers, Salvadorans assert themselves as valid members of the local 
community. Through implicit and explicit comparisons with other social identities - in particular poor Whites framed as "White trash" - migrants perform boundary work against other social groups. They assert themselves as "better" than "White trash," and thus as moral beings, dignified workers and legitimate members of the community. This boundary work is particularly important in staving off the specter of the "illegal alien" whose demonized image circulates so broadly in the United States, although ironically the discourse does so by repudiating another subordinated social group defined by intergenerational rural poverty and Whiteness.

Constructing such boundaries not only protects working migrants from social definition as illegitimate "illegals," it also positively constructs a space of identity, dignity and contingent belonging. In The Dignity of Working Men (2000), Michèle Lamont draws on Barth's (1969) theory of boundaries to examine working-class men's use of morality to construct a "disciplined self" and set up symbolic and social boundaries between "people like us" and other classes of people. Her characterization of her interviewees could as easily apply to Salvadorans in rural Arkansas:

Morality is generally at the center of these workers' worlds. They find their self-worth in their ability to discipline themselves and conduct responsible yet caring lives in order to ensure order for themselves and others .... Workers use these standards to define who they are and, just as important, who they are not. Hence, they draw the line that delimits an imagined community of "people like me" who share the same sacred values and with whom they are ready to share resources. These communities may overlap with, or cut across, class and racial lines." (Lamont, 2000, 3)

Similar to Lamont's working-class subjects, Latino transnational migrants in Arkansas construct a sense of moral self that centers around work and responsibility.

Racial and ethnic difference is socially produced and socially structured through the invention and reinforcement of boundaries of belonging (Barth, 1969; see also Lamont and Fournier, 1992; Lamont and Molnár, 2002) and dependent upon the cultural repertoires and etiquette associated with one's social location (Hartigan, 2010). This investment and affiliation is theoretically and in many cases practically - mutable and situational. For my analysis, I draw on these conceptualizations in conjunction with Omi and Winant's astute concept of racial formation as operational through "common sense," "a way of comprehending, explaining, and acting in the world" that naturalizes the structured inequality brought about through racial projects $(1994,60)$. In this regard, it is instructive to conceptualize the construction of Whiteness, Blackness, and Latinidad rather than simply speaking of Whites, Blacks and workers," and surely discourses and values regarding morality and work travel transnationally along the migrant trail, accruing new connotations in varied contexts. While my data are largely from Salvadoran informants, often the claims they were making were framed on behalf of not only their own nationalorigin group but in terms of Hispanos or inmigrantes as an ethnicized whole. In my analysis, I emulate this shifting practice, replicating the open-endedness of their discursive work. 
Latinos as if these were preexisting social identities. Racial and ethnic identities are always the contingent result of a complex process of chance, context and choice: "Race is neither an essence nor an illusion, but rather an ongoing, contradictory, self-reinforcing process subject to the macro forces of social and political struggle and the micro effects of daily decisions" (Haney López, 1994, 7). As racial formation emerges from social process and demonstrates historical flexibility, it is not surprising that recent migrants from Latin America should actively negotiate their place in local hierarchies by engaging in the agentive construction of local racial meanings.

The construction of Latinidad in rural Arkansas is not merely a product of Latino agency, however, as local Whites participate in this social process. Although many Whites take part in a negative discourse regarding Latino migrants, White elites generally reward Latinos for their crucial roles in the local economy - centered around the poultry industry - with a measure of paternalistic approval, protection and symbolic inclusion. This inclusion hinges on particularly exploitative modes of labor incorporation. The very discursive structure of the claims to dignity made by Salvadoran workers - centering as they do on the morality of hard work and the avoidance of public benefits ironically contain within them the social and ideological mechanisms to reproduce this exploitation. It is no accident that elite Whites echo and foster this discourse of comparison and moral worth regarding "White trash" and "Hispanics" in their community. Such contestations reduce the possibility for solidarity among workers across these socially constructed divides of racial and ethnic difference, construed in terms of morality. In addition, the framing of morality in terms of work contributes to all workers' willingness to endure low wages and poor conditions, as their labor provides less tangible forms of social and moral capital.

The ability of Salvadorans and other Latino transnational migrants to achieve this contingent belonging in small-town United States is significant, and points to the importance of local social geographies in shaping migrant incorporation (see Winders, 2005, 2008; Stephen, 2007; Hirschman and Massey, 2008). From one angle, this is a successful story of the ingenuity of migrants in negotiating local social worlds, as well as an instructive case demonstrating both the fluid dynamics of local ethnic politics in the rural South and the complex and polysemic meanings of Latino migration and "illegality" across sites. From another angle, it is an illustration of the consistent disciplining power of stateproduced categories such as "illegality" and the persistence of neoliberal hegemony and governmentality as it seeps across scales and infiltrates the minutiae of daily life and personal identity (see also Hiemstra, 2010). As Andrew Sayer points out, morality is not external to market-based economic systems, but rather normative frames and economic structures are mutually

3 Sayer draws on Polanyi's notion of constitutive (Sayer, 2006). ${ }^{3}$ With an eye to both facets - the face of agency and the face of hegemony - I explore here the contorted world of identity 
boundaries, moral economy and social belonging in Danville, Arkansas. Below, I sketch out the local landscape and changing demography of the town itself. This is followed by an examination of two crucial and intersecting discursive contexts: the symbolic construction of "illegal immigrants" and that of "White trash." Having located the case study both geographically and discursively, I then go on to describe migrants' and local Whites' engagement in boundary work, and interpret the social and symbolic impacts of this strategic restructuring of ethnic meaning, moral worth and social belonging.

\section{Danville, Arkansas: Heritage and Harmony}

No era siempre así, pero ahora somos como una familia -

a veces peleamos entre nosotros, pero a fin de cuentas estamos unidos. ${ }^{4}$ "Isabel," a Salvadoran-American living in Danville

Although the discourse on immigration nationwide and even statewide was contentious throughout the period of my fieldwork, I was struck throughout by the uncanny quiet and peaceful coexistence within the small town of Danville, Arkansas, which was the primary field site for my ethnographic research. In many ways, Danville is the kind of small town that epitomizes White imaginings of traditional rural Americana. Located in Yell County - an important site in the 1969 Western film True Grit starring John Wayne - this town with a population of less than 3000 is surrounded by rural landscapes dotted with evangelical churches. No country bars mar the moral economy of the landscape; the sale of alcohol is banned within the county limits. Whereas other areas of the US South and West invoke more multiracial imaginaries, the rural Arkansas ethos, like that of the Appalachian mountains, is strongly associated with a timeless and tradition-bound (White) rural American culture, characterized by rugged individualism, personalism and neighborly hospitality, independence and work ethic, and a populist sense of justice. ${ }^{5}$ As such, I expected to find overt public contestation over the transformations of social and public life following on the influx of immigrants from Latin America and Southeast Asia, based in White residents' sense of a loss of heritage. This is not entirely the case and, in fact, the presence of migrants (a boon to the local economy) has been largely supported by local Whites.

Immigration to the area occurred over the past 15-20 years due in large part to the growth of the demand for poultry production and a scarcity of willing local labor to staff the chicken processing plants. In-migration first of Laotians (during the 1970s and 1980s) and then, Latinos (mid 1980s through the present) went hand in hand with an economic revival in this small town: poultry plants were able to maximize their production, boarded-up businesses on the old Main Street were renovated and new small businesses built and the population of the "embeddedness,"

but expands

beyond this to

assert that

economic

institutional

structures not only

depend on certain

moral

preconditions, but

also are entangled

with the

psychological and

social

interdependence of humans as they

seek validity and

recognition

through their

economic roles

(Sayer, 2006, 82-87).

4 “It wasn't always this way, but now we are like one big family [here in Danville] - we might fight amongst ourselves, but at the end of the day we are united."

5 In the context of recent reactionary political

movements as well as conservative constitutionalism, this imagined rural heritage has acquired new caché as it is symbolically associated with other narrative/ normative notions of authenticity. 
6 One informant indicated that he had a brick thrown through the window of his car in the early 1990s, and he believed this incident to be racially motivated. Another told me that a local White had hit and killed a Latina woman with his car and had escaped with impunity. These tales were nearly always prefaced with a remark such as "things like this don't happen now." This lends evidence for the idea that it is not merely the utility of labor, but also the discursive strategies of boundary work, functioning over time, that foster incorporation and recognition.

7 Salvadorans themselves recognized the contrast between local conditions and the national turn against Latino migrants. One interviewee, after stating yo sé que aqui no me quieren - "I know that they don't want me here" - hastened to add that he felt welcomed by most town doubled during the last few decades of the twentieth century. A few scattered tales of harassment, discrimination and police abuse in the 1990s appeared in my interviews, suggesting that the harmony I perceived had been won at the end of a period of greater social conflict and adjustment. ${ }^{6}$ This town was a site of social harmony and relative integration for my Salvadoran informants during the time period covered by my ethnographic research (20052008) - the same time period when at the national, regional and Arkansas state level, Latino immigrants were frequently demonized and subject to increasing levels of federal enforcement, surveillance, discrimination and hate crimes. ${ }^{7}$

Social incorporation and amicable relations within Danville are linked to the discourse on work and morality spun by Latino migrants in Arkansas. Like Lamont's interview subjects in her study of working-class constructions of morality, migrants have been able to construct boundaries between themselves and other social categories, achieving self-respect and social recognition in a highly constrained context. This construction of social validation around the figure of the "hardworking immigrant" mitigates both the instability and the disciplining effect of legal exclusion - particularly the condition of "illegality" on the working lives and identities of transnational migrants. Yet the functioning of this contingent belonging is embedded within the reproduction of economic inequalities and social hierarchies in the rural US South through racial and class formation. In order to comprehend the claims to dignity made by Latinos in Yell County, in other words, we must also contend with the ways in which such claims may be mutually constitutive of structures of inequality.

\section{The Social Life of Illegality: Racializing and Demonizing Latino Immigrants}

\author{
We've got so many illegals here, it's unreal. \\ "Debbie," a white resident of Yell County
}

To be undocumented is to lack state permission to be present in the national territory - a violation that is civil in nature, not criminal. Nonetheless, the condition of being an unauthorized migrant has ramifications far beyond the legal sphere. The concept of the "illegal alien," a technical term in a complex legal framework, circulates through social worlds and becomes embedded in elaborate narratives of threat and transgression that intersect with racism and reactionary politics. Recent work on the political economic function of "illegality" emphasizes the way this racialized condition contributes to the manipulation and control of migrants by state institutions and economic elites (Ngai, 2004; Willen, 2007; Bacon, 2008). The circulation of the notion of "illegality" in popular discourse couples with the state's spectacular modes of detention and enforcement to achieve, not the removal of undocumented 
workers, but the continued reproduction of a subordinated class of foreign-born workers to fill particular roles within the economy. Rather than an "exception" to neoliberalism (Ong, 2006, 4), therefore, undocumented migrants are absolutely central to neoliberal regimes.

The concept of the "illegal alien" became indelibly associated with racialized Latinos (often glossed as "Mexican") by the middle of the twentieth century (Ngai, 2004; Sadowski-Smith, 2009, 277-279; Romero, 2011). By the early twenty-first century, the "Latino threat narrative" entails widely circulating notions that Latinos pose a threat to the cultural heritage and physical security of US citizens, through supposed resistance to Americanization, inappropriately high fertility rates and a plot to retake "Aztlán," the territory of the US Southwest (Chávez, 2008). These notions produce a "common sense" that frames Latinos, even US-born Latinos, as unsuitable subjects for the possession and exercise of US citizenship.

Anti-immigrant discourse often uses metaphors of illness or invasion, suggesting that undocumented immigrants, or "illegal aliens" in the parlance of many of these sources, are a threat to others in the country. Some native-born people in new immigrant destinations conceive of the migrant as a social parasite, whose allegedly inappropriate use of public services and unearned advantages in the job market threaten the interests and drain the resources of the native-born population (Fennelly, 2008). Circulating notions of the "illegal alien" thus involve contradictory assertions that the "alien" is too hardworking and threatens native-born workers' jobs and wages, while also claiming that the "illegal alien" is lazy and dependent. ${ }^{8}$ The accusation of dependency - of failure to work and earn one's way in society - is central to a discourse in which the migrant is framed as "having no rights" and as a source of social pollution - as a transgressive body. ${ }^{9}$

Many Latin Americans and Latinos living in the United States are also racialized, and in many locations - especially new immigrant destinations where a disproportionate number of Latino residents are more recently arrived in the country - belonging to that "race" is conflated with illegitimate presence regardless of legal status. This narrative construction of Latinos as automatically "illegal" and therefore illegitimate residents was certainly operating in rural Arkansas, and numerous White informants implied or stated that "Hispanics" in town received unfair access to public services, had preferential treatment in the workplace and were likely to "take over" the town. A few White interviewees in Yell County articulated a sense of both local and national belonging that was strictly racialized - for example, one informant stated "I think they should send all the Mexicans back to Mexico, all the blacks back to Africa, and all the Asians back to Asia" ("Sharon" 25 September 2007). ${ }^{10}$ Several others expressed a sentiment that similarly depended on White normativity while avoiding explicit reference to race - for example, one woman stated "if they keep letting the local people but rejected by $e l$ gobierno, the federal government ("Mauricio," 16 September 2007).

8 Oversexed and potentially violent, simultaneously too industrious and too lazy, this image of the "illegal alien" has an uncanny similarity to racialized depictions of AfricanAmericans as a "threat" to White Americans, particularly in the post-

Reconstruction south (Moneyhon, 1997).

9 The criminalization and dehumanization 
of migrants takes place within the broader context of other policy movements that have, with some success, sought to redefine questions of racial justice into issues of poverty and criminality and thus constitute non-Whites as embodiments of "social problems" and appropriate objects for state intervention and discipline

(Weaver, 2007; Wacquant, 2009; Alexander, 2010). Action against "aliens" or Others can be a powerful mechanism by which the state creates public displays of power and efficacy, a performance of sovereignty (Comaroff and Comaroff, 2005, 144).

10 Interestingly, this interviewee was also a landlord whose income depended on Latino renters, both temporary workers and permanent residents. She reconciled this with reference to practicalities, using a frame emphasizing illegals in, this country will be different - it just won't be America anymore" ("Kelly" 8 April 2008).

Although Whites in Danville expressed appreciation and acceptance of their migrant neighbors, this did not preclude their acceptance of the threat narratives about the "illegal alien." Positive discourse regarding Latino migrants as "good neighbors," "good people" and "good workers" often coexisted with criticisms of "illegals," and most Whites did not seem to find these to be contradictory. This dual conceptualization enabled a structured ambivalence toward migrants in which Whites could carry on intimate friendships with some undocumented migrants, extending even to a willingness to sponsor them for residency, while simultaneously justifying the exclusion of others who are deemed unworthy. In this context, boundary work emerged as a crucial social tactic for individual migrants to frame themselves on the "good" side of this binary moral divide, helping them to distance themselves from the potential ascription of social worthlessness.

In Danville, "illegality" permeates social conditions in a way that transgresses scalar boundaries, operating simultaneously at such disparate levels as the scale of global political economy, the scale of national belonging and the scale of individual identity (see also Hiemstra, 2010). ${ }^{11}$ Recent scholarship adds to political economic insights regarding the structural function of "illegality" for late capitalist regimes by noting that such a condition also pervades migrants' local social incorporation and even individual subjectivities, rendering ambiguous and tenuous any sense of belonging or legitimacy (Coutin, 2005; de Genova, 2005). Caught in the vexed position of simultaneous invisibility (as legitimate legal and social persons) and hyper-visibility (as racialized Others), transnational Latino migrants experience "illegality" not merely as a civil status but as an ontological condition. Chávez and Gonzales (2008) argue that such a condition might more usefully be conceptualized as "abjection" rather than "subjection." The law's refusal to recognize migrants' personhood does not allow them to "escape" or "transgress" the legal order, but on the contrary structures a particularly invasive form of discipline. Latin American migrants learn to frame their aspirations in ways that conform to and reinforce dominant values, thus strategically asserting themselves as "neoliberal citizens" whose legitimacy is based on worker and consumer identities rather than political status (see also Chávez, 2008).

The impact of "illegality" upon migrants, therefore, extends far beyond the punitive potential of deportation, or even the control and exploitability of labor. "Illegality," with its double reverberation in both legal and lay discourse, becomes a pervasive condition that shapes migrants' experiences, social incorporation and even identities. Within the small scale and relatively closed social world of rural Arkansas, Salvadorans and other Latinos hastened to avoid being classified as illegitimate or "illegal" by the means at their disposal, and met with a surprising degree of success in asserting themselves as legitimate 
residents. In a way, they have been able not only to assert themselves as legitimate, but even insert themselves in an advantageous social position within the essentialized class hierarchy of rural Southern Whiteness.

\section{Stratified Whiteness: Intersections of Class and Race}

I hope nobody went too redneck on you.

$$
\begin{array}{r}
\text { "Stan," commenting on my other white } \\
\text { Yell County interviewees }
\end{array}
$$

The river valley region of central Arkansas, tucked between the Ozark and Ouachita mountains, has an official history of racial uniformity. Unlike the post-plantation regions of the US South - such as Eastern and Southern Arkansas - Central and Northwest Arkansas has been predominantly White for a few centuries. Nonetheless, Whiteness in this context is ambiguous and contested; there are long-standing hierarchies among Whites based on class status. Differences of class among Whites in central Arkansas, as in many other regions of the United States, are often glossed as hierarchies based on moral responsibility as well as biological superiority. The poverty of poor Whites is framed in popular discourse as justifiable through the representation of poor Whites as morally lacking, dependent, culturally "backwards" and even as genetically inferior (see Cash, 1941). There is a regionally specific dimension to this hierarchy, however: the Ozark and Ouachita mountains, much like the Appalachian mountains, have been represented in the national imagination as a backwater, home to diverting and picaresque White rural residents, "survivals of a primitive society," to quote the title of a 1931 treatise by Vance Randolph. Images of inferior Whiteness have been extant since the earliest written accounts of White settlers and travel writers on Arkansas. In George Featherstonehaugh's memoirs from his travels through Arkansas in 1834 and 1835, he describes Arkansas as a "society of outlaws," a crude and violent home to debtors, gamblers, forgers, horse thieves and murderers, drawn to the area by the absence of law enforcement and social rules regarding private property and ethical behavior (Bolton, 1998, 90; Bolton, 1999, 1). The historical figure of the "hillbilly" continues to haunt these parts, just as the ghost of John Wayne continues to figure in the rugged individualism, anti-unionism and stoicism that characterize local moral economies. In other words, the mountainous areas of Northwest Arkansas have been conceptualized not only as a site of valued heritage, but simultaneously as the homeland of an inferior subspecies of human being - "White trash."

The term "White trash" emerged in tandem with eugenics movements in the latter half of the nineteenth century, and this degraded social category was sometimes defined by eugenicists as "worse" than some communities of color, a
Latinos'

dependability: "It

comes down to,

they pay on time, they keep out of trouble, if they're a family they're very well kept, and they keep to themselves"

("Sharon," 25

September 2007).

11 Arguing that

"illegality"

functions as

Foucauldian governmentality, Nancy Hiemstra demonstrates that in the small mountain town of Leadville, Colorado, "illegality serves as a primary technique for controlling the local population in ways that establish and maintain the neoliberal order" (2010, 94). 
12 As both Wray and Hartigan signal, these comparisons were closely linked to the intra-racial and inter-racial politics of antislavery movements. particularly salient and frequent comparison made with African-Americans in the rural South (Hartigan, 2005, 59-67; Wray, 2006, 47-64). ${ }^{12}$ During this post-Civil War era, the figure of the poor White Arkansan came to dominate perceptions of the state, reflecting the growth of the population of disenfranchised Whites who were economically marginalized:

At the bottom, at least as perceived by those above them, was a lower class consisting of tenants and laborers. They were, in short, the landless members of a rural society. This group steadily increased throughout the late nineteenth century as economic conditions worsened and came to represent a larger and larger segment of both the white and the total population. The more successful members of the community considered the landless not only poor but possessing unique class characteristics. Terms applied to them, such as "poor whites," "white trash," "rednecks," or in the mountains, "hillbillies," were loaded with meaning and suggested that this class was not only poor but also lazy and uncouth - they brought poverty on themselves through their behavior. (Moneyhon, 1997, 13)

The tenant system that many of these families worked under kept farmers poor and exploitable through debt and exclusive contracts (Agee and Evans, 1939; see also Moneyhon, 1997, 7, 76 on the life of tenant farmers more broadly). This regime of production was remarkably similar to the current system of contract poultry growers. The cultural formation of denigrated poor Whiteness, while embedded within economic structures, was interpreted and the boundaries maintained through moralizing discourses.

John Hartigan Jr., in his recent work on the sociocultural construction of Whiteness, demonstrates the linkages between constructions of "White trash" and dominant cultural constructions of morality around work and independence: "The fundamental basis for objectifications of this group arose from this moral categorization of those who will and will not work" (2005, 67). Persistent class hierarchy and the existence of "redundant labor" (the chronically unemployed at the margins of regimes of production) was also naturalized through concepts of inbred bloodlines or other genetic explanations, although eugenicists were flabbergasted by the seeming racial "purity" of these socially degraded subjects and searched avidly for genetic explanations (Hartigan, 2005, 76-88).

Hartigan also demonstrates that racial status as "White" does not everywhere and always translate easily into White privilege (Winders, 2003, 45-46; Hartigan, 2005, 14; see also Wray, 2006, 16; Hartigan, 2010, 92). In his case study of urban Whites in Detroit, Whiteness lacks the privilege of invisibility (Hartigan, 2005, 209-210). Whites in working-class Detroit neighborhoods also often come from historically marginalized groups, therefore experiencing their Whiteness not only as racially marked but as potentially slipping into 
denigrated status as "White trash," read through a discourse of morality, hygiene and social propriety (Hartigan, 2010, 109-111). Unlike the Detroiters studied by Hartigan, Whites in Yell County do not occupy a social landscape where Whiteness is marked as an outsider status - although it has certainly become less unmarked with the demographic transformations of the past few decades - but they similarly had to consider the dangerous possibility of being framed as "White trash."

The reality of stratified Whiteness in this particular region of the US South complicates the social context Latino migrants encounter arriving into supposedly "homogeneous" White communities in the case of North West Arkansas and the Ozark and Ouachita mountain regions, making this a very idiosyncratic site of settlement in terms of existing and potential racial formation. Whites' identities within this essentialized class hierarchy play a large role in their response to new immigrant groups. In addition, Latino residents quickly grasp these divisions and seize on the critical discourse toward poor Whites, utilizing these cultural formations in their moral boundary making and bids for social inclusion and worth.

\section{Bounding the Moral Migrant: Assertions of Hygiene, Work Ethic and Independence}

¿Será verdad que existen estos blancos, allí en las montañas, puro campo, que son muy, pero muy primitivas? Dicen que nunca se bañan, y hasta se casan con los primos.

$$
\text { "Alfonso" on the elusive Arkansan hillbilly }{ }^{13}
$$

"Hillbilly" is inherently a mythologized cultural construct, a symbolic other whose hyperbolic social conditions are distanced by the isolation of the mountains. Similarly, although aspects of the discourse of trash are deployed toward particular White individuals at particular moments, "White trash" is not a descriptor for an actual social group as much as a symbolic placeholder that represented the traits and qualities of socially undesirable, morally unworthy subjects. As Hartigan explains in his overview of the history and cultural function of the term in the United States, “... White trash is neither just a name nor a distinct social group. Rather, it is a form of objectification developed by a range of social commentators who tapped the cultural perception of pollution" $(2005,106)$. The social functions of this objectification include naturalizing systemic inequality, justifying social interventionist policies such as forced sterilization (see also Wray, 2006) and disciplining specific social groups who fear becoming polluted (Hartigan, 2005, 78, 106-107).

Salvadoran acquaintances of mine frequently criticized the hygiene and child-rearing practices of their working-class White neighbors, and 
circulated tales of poor Whites who lived in the backwoods, puro campo, who supposedly refuse to work, living in squalor and ignorance. One informant compared Salvadoran norms regarding hygiene with the local poor Whites in this way:

Here some people are too careless (descuidado), especially with their children, and it's not good. In El Salvador mothers are expected to maintain the hygiene of their children - doctors will reprimand them if they come to a checkup with their fingernails all black with dirt ... and it is difficult to maintain hygiene (aseo) with children in the countryside, when one is poor. But even if one doesn't have soap, one borrows from the neighbor to wash the children. ("Isabel” 3 March 2007)

The use of cleanliness as a boundary marker is common, especially in relation to poor Whites, and forms part of the broader phenomenon of "body work" in which social orders and hierarchies are naturalized through inscription on bodies - particularly markers of cleanliness and filth, etiquette and decorum (Hartigan, 2005, 258).

Attributions of laziness to poor White neighbors were also common sources of conversation, often linked to tales of the exchange of social security numbers. Gossip circulated regarding young women willing to sell their social security number - or in some cases simply loan it - to an enterprising Latina, so that they could appropriate the tax return check:

Sometimes people don't even sell [the Social Security number], they just give it away, because if they are working for cash ["under the table"] or they don't want to work, it's better for them [les conviene]. There's a lazy Americana [white] whose name is Joy; she has two kids and doesn't want to work. Her husband fell for a Mexican girl, and that girl started working under Joy's name - Joy is complicit with it all, she even took the girl to get a driver's license with her picture, using Joy's birth certificate. Imagine! ("Elena," 28 March 2008)

As in this case, often sexual morality is also questioned within these narratives.

Among the Salvadorans that made up my primary research subjects, this boundary work was sometimes deployed to distinguish Salvadorans from Mexicans. Attributions of moral failure or laziness toward Mexicans became a way to construct ethnic difference as well as express resentment at being called "Mexican" by local Whites and mitigate other historical tensions and categories of difference extant in the Mexico-Central American regional context (see also Arias, 2003; Stephen, 2007, 209-215). These discursive practices of boundary making are mutually constituted with practices of 
informal social segregation - for example, in seating in the break room at the poultry plants and in the high school cafeteria.

\section{Raza trabajadora: The Dignity of Working Migrants}

Me gusta cumplir con mi trabajo. ${ }^{14}$
14 "I like to fulfill my work."

Magdalena, born in El Salvador in the 1950s, held numerous jobs in Southern California in the years before she moved to Arkansas. She worked mainly in the informal economy, either in domestic care or in clandestine textile factories commonly called "sweatshops." Twice she had been a victim of wage theft and had received no payment for work she had done, once after a "blowup" with her mistress (señora) when she was working as a nanny (see also HondagneuSotelo, 2007), and once after completing a shipment of designer clothes.

In spite of the indignities and injustices she described, in speaking of these jobs her manner was frequently one of pride and humorous reminiscence. She spun entertaining tales of childish, self-centered employers, emphasizing their helplessness and dependency. She claimed to have saved the life of at least one elderly man whose life expectancy stretched from 6 months to 4 years, thanks to her illicit daily use of chicken foot broth. Even her current job in Danville, removing the internal organs of chicken carcasses as they speed by on metal spikes in the cold, odorous inside of the most notorious processing plant, was always described in affectionate terms. She spoke frequently of her good relationship with her supervisors, her efficiency on the line, her dependability, her competitive working speed and her refusal to take breaks in spite of her recurrent medical conditions. The statement "I like to fulfill my work," was made on the first day we met, as Magdalena described her dismay at having to miss a day of work to go to the hospital.

The first time we sat down to talk over cups of hot tea, Magdalena proclaimed "No soy uno de esas que tiene miedo al trabajo / I'm not one of those people that's afraid to work," a catch phrase that I would hear her repeat dozens of times in our frequent and lengthy conversations. She approached many topics with this characteristic bravado, "I'm not one of those that's afraid of the migra," for example. Yet the theme of work in particular and the centrality of laboring life to her identity and self-respect emerged again and again. Although her articulation of this pride and identification with work was exceptionally strong, it was by no means unusual among the Salvadorans I spoke with. Most work difficult, stressful, low-status jobs on the disassembly line at poultry plants, yet affinity for work is celebrated as an enduring source of pride, self-worth and social validity. It is also deployed as a form of boundary work, as many expressions 
15 Similar to

Lamont's

working-class

subjects, she drew

boundaries

against the

professional and

managerial

classes as well as against the poor although the

boundaries drawn

toward those

"above" were

more ambiguous

and contained a

degree of

admiration,

whereas those

"below" were

characterized in a

less sympathetic

light (Lamont,

2000, 100-114).

16 While this case explores a local manifestation of this trope, the concept of the Latino immigrant as a "preferred worker" - one who is willing to work harder for less and "do jobs Americans won't do" - is not of this pride are explicit or implicit comparisons with unfit or unethical workers - "those people" who are "afraid" to work hard.

Magdalena's coherent personal narrative centers on a powerful form of work ethic, holding that all workers should work conscientiously regardless of treatment by supervisors. She frequently decried the complaints of her peers and criticized most coworkers' attempts to make claims on the company in the form of worker's compensation or other benefits. She did not complain about the stagnation of her wages over the 8 years of service to the company, or the fact that her health insurance covered very little of her medical needs. At the same time, her attitude as a worker is far from submissive, and her view of the realities of economic relations far from naive. She commands respect at work, and she was willing to make claims and demands for wages when due. She criticized the moral failings of supervisors and bosses as well as those of working-class peers. ${ }^{15}$ Yet by embracing labor and work ethic as central to her identity, Magdalena mobilizes a recognized cultural repertoire and situates herself in a favorable moral position, a space of dignity (see also Lamont, 2000, 243-248).

Salvadoran migrants presented themselves as uniquely suited to work; in particular, they framed their claims by drawing ethno-racial boundaries claiming that jobs they held were not desirable to - or even possible for White US citizens. One man said, "we come to look for these jobs, it's true ... but I think that this is not work suited for the Whites." He went on to say that Latinos have a compulsion to work that extends even beyond the capacity of their bodies to endure:

It's possible to see a Hispanic who faints on the line, but doesn't quit. That is to say, the body can't go on but the will [to work] is still there. Even if we can't do it, we do it [aunque no podemos, lo hacemos]. Before, only two chickens went by per second, now it's a lot more. ("Mauricio" 16 September 2007)

In this discourse, the ability to do work that others cannot or would not $\mathrm{do}^{16}$ is essentialized and transformed from a structural necessity to a point of pride, a racialized identifier differentiating Latinidad from poor Whiteness. In Mauricio's narrative, even the increasing line speeds that have been part of the Taylorian efficiency reforms in poultry processing- reforms that have had a devastating impact on worker's bodies (Ollinger, 2005) - is attributed to the superior nature of Latinos as fast workers.

Migrants express a sense of self as always and indefinitely ready to work, and also discursively connected work ethic with other forms of traditional morality such as a refusal to take illegal drugs:

I am accustomed to working, and I like work. People even tell me that they never see me get tired because if the line stops, I look around and try to 
help others, I turn around to the other line [behind me] ... That's why people ask me why they never see me get tired - what do I do, or what do I take. And I tell them nothing, thanks be to God I never take drugs, only vitamins. ("Carmela” December 2007)

As in the discourses on morality spun by working-class men, both White and Black, morality here is conceived as a property or essence of a person, an essence that is revealed through their behavior in conformity to particular standards most crucially individual responsibility and work ethic, but also other aspects of traditional morality (Lamont, 2000, 24).

As for Lamont's subjects $(2000,132-136)$, the refusal to claim public services is also a critical part of this moral boundary work. One interviewee stated plainly the association between refusal of public resources and the commitment to work: "we come here because there is work. It's for work that we come ... we work, we do not live off the government. Living off the government, I really don't like that" (“Alberto" 8 March 2008). Carlos, a Danville resident who sells tacos out of his van in the parking lot of one of the poultry plants during break times, used to work on the "disassembly line" in the evisceration department at the plant. He repeated one motion over and over as the chicken carcasses flew by at high speeds impaled on spikes until he injured his fingers at work and was no longer able to keep his job. At first, he claimed that he did not take disability benefits after being injured at the plant because he takes pride in his independence. In his words, Americanos [Whites] may take welfare money instead of working, but he would never do that - even hurt, he will find some way to work, to vivir honesto or "make an honest living." By asserting his refusal to take public benefits, Carlos constructs a moral and social boundary and situates himself favorably in a local moral economy of work vis-à-vis others by implication, poor Whites. At the same time, he is actively contributing to a neoliberal moral economy of value that frames the use of public benefits as invalid and a sign of problematic "dependency."

Others commented on their unwillingness to take benefits while emphasizing their legal eligibility, thus underscoring the moral imperative as well as connecting this stance to other aspects of traditional morality such as drinking alcohol:

Some of the Americanos [Whites] are content to just live off the help of the government .... There are women who have two or three children and then they say "now I can't work." They prefer to live off the state, even though they live poorly. The immigrant does not do this, the immigrant what he does is work and work in whatever he has to - only work and work and never ask for help. Even I as a citizen, I try not to ever ask for help... you know that we try not to live with any vices, not tobacco nor alcohol, so that we can earn our own living. ("Isabel" February 2009) unheard of in both nationallevel and other local discourses (HondagneuSotelo, 2007; Gleeson, 2011; Valenzuela and Fussell, 2011). Often deployed strategically to counter nativist claims, this narrative entails significant costs as it establishes a binary between the "deserving" and

"undeserving" migrants, as well as reifying the idea that inmigration to the United States should be evaluated only in terms of its impact, positive or negative, on existing citizens (see also Gleeson, 2011). 
17 "Out of 10

[White]

Americans, perhaps two would see you badly, but the remaining eight will actually even jump in to defend you."

18 This essentialized representation is similar to the discourses analyzed by Arlene Dávila in Latino Spin (2008); these discourses valorize the Latino community through the deployment of sanitized celebrations claiming Latinos are "more American than the Americans."
The dominance of this discourse of morality linking hard work, responsibility and independence shaped migrants' identities, motivations and choices. It was also clear that this discourse helped to shape the local moral regime - a regime that depended on a racialization of particular forms of work and the construal of Latinidad as a natural fit within local systems of production. The symbolic construction of Latinos as "good workers" circulated among Whites as well, proving to be a narrative with purchase in the broader social field.

\section{"Better Than White Trash": The Fruits of Moral Boundary Work}

De diez Americanos, quizás dos de ellos te ven mal, pero los demás ocho muchas veces hasta se meten a defenderte. "Mauricio" 16 September $2007^{17}$

Upper- and middle-class Whites in Yell County frequently expressed admiration for "Hispanic culture" - the family values, work ethic and strong religious faith that supposedly characterized the migrant community. ${ }^{18}$ This essentialist frame assigns positive value to the moral status of Latino migrants, often buttressed by the simultaneous denigration of poor Whites. When I inquired his opinion of the newcomers within a few weeks of my arrival, one pillar of the community in Danville stated "they're hardworking people, they're good neighbors, I mean - they're a lot better than the White trash that was there before them!" A friendly older White lady who I met having lunch at the Salvadoran restaurant on Main Street said:

If it weren't for the immigrants, this town would keel over and blow away. We need those chicken plants. Education is great, I love education, but then there's nobody left to work. And that's why these Hispanics come, is to work. The families are good, Christian people, good neighbors. ("Ethel” 25 March 2007)

Ethel's statement expresses a typical claim made by many interviewees both White and Latino - that Latin American migrants arrived not to compete with local White labor, but to replace and supplement them as workers retired, young Arkansans left the area to pursue higher education and consumer demand for poultry continued to rise.

Middle- or upper-class Whites are less likely than their working-class White neighbors to have Latino in-laws or friends, yet they work to maintain positive public discourses regarding demographic change. Although elite White interviewees usually mentioned a sense of uneasiness regarding the rapid demographic and cultural transformation of their hometown - during 
the period of my fieldwork, the town was around 50 per cent non-White they nonetheless performed a stance of generosity and appreciation toward Latinos. The civility of these relations is precariously balanced on legal and social structures of exclusion. Salvadorans, Mexicans and other Latin American migrants are welcomed in part precisely because they are politically disenfranchised and economically disciplined. Nonetheless, this delicate balance provides opportunities for migrants to strategically assert themselves: by being the proper kind of subject, they can acquire a measure of social recognition, advocacy and protection on the part of the "good old boys." Similar to the ability of the Chinese settlers in Mississippi to negotiate their place favorably in a local racial hierarchy (Loewen, 1971), Salvadorans in Danville are able to assert themselves as valid residents and "good neighbors" during a time period when the climate of reception nationally and state-wide was hostile. ${ }^{19}$

In Danville, intimate and paternalistic relationships sometimes develop between Latinos and Anglo supervisors or bosses in which Whites become both friends and defenders. Rubén described his first boss, the man who recruited him from Texas, as a teacher and protector:

He was a good boss (patrón), as a boss he was good. He was responsible with us, he paid on time and he took care of us. When we were going to have a few months without work he would say to us, 'we're going to be without work, take care of your money, don't spend too much, because we'll go two months with no work!' And if one of us was spendthrift he wouldn't lend us money. But if we were careful with our money but still had a true emergency, and we really had a need, then he would help. (“Rubén,” 3 August 2007)

These Anglos will speak on behalf of migrants, often utilizing the claims of the moral discourse regarding work. Mauricio spoke of an ex-supervisor of his who got into an argument with another White man who was spouting negative views of migrants:

I have a great friend, I would even give my life for him, he's an American and his name is George Hill, from Russellville. He speaks a little Spanish, and I only speak a little English, but anyway, we became friends. He appreciates me a lot. We worked together, we went out to eat together, everything. One time he got mad at another American. I didn't understand what they were saying, but later he explained to me that this American was saying that we don't pay taxes, that we came to take their jobs away, and things like that. My friend got mad and he said to him, look, I'm a supervisor at Tyson, here are the applications if you want to work. I take taxes out of their checks, and afterwards
19 The personalism of this setting has parallels to the clientelism of Salvadoran rural communities during the period of the cafetales, plantations run by large landowners. This familiarity with the social rules of conservative and relatively closed political environments gave many Salvadorans a sense of agency in establishing their presence. 
20 Like many who work under the Temporary Protected Status work permit program, Magdalena had submitted her paperwork for renewal but the US-CIS processing was delayed far beyond the expiration date of her permit.

21 Grey and Woodrick (2005, 140-144) similarly describe the variegated responses of Anglos in Marshalltown, Iowa to new migration from Mexico. A vocal minority of they don't claim the refund because they can't or they don't know how. That money goes to the government - and do you know why? To give to you because you don't want to work! ("Mauricio," 16 September 2007)

In this anecdote, boundary-making discourses circulate and cross barriers of language as the Anglo supervisor counters the anti-immigrant discourse of another White man. Reversing the "Latino threat narrative" in which foreignborn migrants are a drain on resources, this defensive discourse attributes dependency to the native White who does not "want to work" and suggests that he is unfairly supported by the labor of hardworking Latino migrants. After the argument, as George recounts the conversation to Mauricio, the Salvadoran man acquires another potential frame for his own discursive work. In this way, the discourse of Latinidad and Salvadoreñidad as moral workers accrues meaning from various cultural repertoires.

At times, migrants can even deploy the claim of "preferred worker" actively to dispute poor treatment or the potential of dismissal. When her doctor required Magdalena to wear a catheter while working in 2007, her immediate supervisor wanted to fire her and claimed that her condition was holding up the line speed. Unable to legally fire her because of her medical condition, he looked for another justification and claimed that her work permit was expired. ${ }^{20}$ She went above her supervisor to the head of human resources, "I told him, I have worked here for years and it would be a great mistake to fire me - on my normal days, I work twice as fast as the others on the line" ("Magdalena," 21 September 2007). Not only did the human resources director preserve her job, he moved her to a less strenuous post while undergoing treatment. In a legal context euphemistically known as a "right-to-work state," Magdalena was able to successfully parlay her moral capital into continued employment as well as better treatment.

Recognition extended by patrones is crucial, but protections provided by local public agencies are no less critical. Those working in public services in Danville - educators, bureaucrats and police - frequently described Latinos as replete with moral virtues, such as investment in education, respect for authority and "family values." 21 Avoidance of public dependency was also a crucial point of recognition. The director of social services for Yell County said that Latinos did not take advantage of public services in the same way that poor Whites do:

The nice thing was once they got jobs and got their first paycheck, they never came back. They don't come back. And I thought that was a real credit to them. That's what so many of our programs are supposed to do, is help you through an emergency situation. And that's how they use them ... you don't see the repeat performance that you have with our, you 
know, typical welfare clients that we've had for generations... their grandparents, their parents, and them on welfare. That's our typical welfare family and you don't see that with the Hispanic population. (P. Pyle, personal communication, 27 July 2007)

By evoking the "you know, typical welfare clients," this public servant implicitly deployed the recognizable image of poor rural Whites and drew a firm moral boundary between these "illegitimate" users of public services, and "the Hispanic population" whose limited use demonstrated the appropriate values of independence and work ethic.

The police force was also seen, contingently, as an ally for many in the Latino community. While a number of migrants told stories of police harassment "in the beginning" - during the early 1990s - they hastened to assure me that the current attitude of the city and county police was quite different. As one informant said:

Here even the police know you, because they know everyone's face, and that's good. They are attentive to every little thing. They know where you are coming from and where you are going. And if you just go back and forth to work, and back and forth to church, they will never bother you. ("Roberto" 3 February 2007)

As Roberto implies, however, migrants did not always feel free to move around if they were not merely going "back and forth" to work or church.

My interviews with local police backed up these comments by Latino residents, as leaders in the law enforcement community all expressed a commitment to treating Latinos equally as members of the community, while expressing a moralistic "law-and-order" ethos that suggested a high level of surveillance over the activities of residents. As law enforcement officers in a county where alcohol is prohibited, such fusions of morality with law are not surprising. Police also enforced an insider/outsider boundary by heightening surveillance on people who had recently arrived from out of the area - policing the Latin American workers who passed through town temporarily each year as work crews in the national forests, as well as keeping an eye on the activities of visiting ethnographers with New York state license plates.

Local law enforcement cracked down on a small group of anti-immigrant protesters organized by White Revolution, a White supremacist group who rallied in Danville several years ago. Police arrested several of the activists and made it clear to the others that they were not welcome. As the current Yell County Sheriff described it,

They got this group called the White Revolution up past Russellville, and the leader of this group married a girl from around here. So a couple years
Whites were outspoken in their opposition to the presence of Latinos and worked publicly to denounce the "problem of illegal immigration" through media and political channels. As for community leaders, as in Marshalltown the political players in Danville were overwhelmingly positive about Latino migration and framed their stance as both inclusive and protective. In the Iowa case, Grey and Woodrick interpret this stance on the part of leaders and public institutions positively and see the town heading toward successful integration (2005, 151-152).

Alternate interpretations such as the one I offer here might emphasize the paternalism in this "protective" stance and highlight the potential for reproducing persistent inequality over time particularly through the construction of 
new racialized hierarchies and social meanings.
22 As the incident discussed here occurred before the period of my fieldwork (20062008), I do not know the composition of the group of protesters in terms of class status, or whether the issue of work and work ethic was truly central to the discussion on the day of the encounter between police and White supremacist activists. The analysis here is ago he wants to come down here and have a protest, he thought he was going to incite the Revolution in Danville. I suppose he thought he'd mobilize a lot of folks down here but he only incited about 4 or 5 people to make their white revolution, it was pretty pathetic really. I mean people around here aren't interested in that kind of thing. (B. Gilkey, personal communication, 26 February 2008)

A few Latinos who described this same incident to me joked that los ricos, the rich people, must have sent the police to get rid of the White Revolution in order to protect their profits. Without the Latinos, they said, where would they make all their money? According to Elena,

Mr Chambers [the owner of Petit Jean Poultry], the owner of Wayne Farms, and the owner of the Sav-a-Sum went to [the protesters] and said no, because it was through the Hispanos that they [the owners] had earned more money. The others said it wasn't fair, because they were poor, and Mr Chambers said if they were poor it was because they didn't want to work. And it was true, they were from here, they could have worked if they wanted to. They arrested them all and took them away. ("Elena" 28 September 2007)

In this astute reading of the situation, Elena also describes a public instance of the circulation and reification of moral discourse constructing a boundary between worthy "Hispanos" and the unworthy poor Whites. White protesters' claims to poverty ${ }^{22}$ and their perception of unfairness in the system were dismissed by a poultry plant owner through his declaration that their condition of poverty was their own fault: they lacked the appropriate work ethic. Elena then picks up on and reiterates this narrative - "it was true ... they could have worked if they wanted to." She utilizes this story to reinforce the moral boundary between hardworking Latino migrants and "lazy" local poor people. It is significant that she highlights the issue of work ethic more than the issue of racism, while speaking of those who openly affiliate with the cause of White supremacy.

As Elena's account also emphasizes, self-interest plays a part in many local Whites' pro-immigrant stance. The poultry industry is the lifeblood of the county. As local state representative Nathan George said, "Interesting situation in this county, it's changed in my lifetime ... but we have no choice if we want to keep the poultry industry, which we've got to have" (N. George, personal communication, 25 February 2008). The benefits and forms of protection experienced by migrants have their nexus in the worker-employer relationship, but in the small town world of Yell County they have come to extend to local law enforcement and government. Social practices of inclusion, surveillance, moral differentiation and boundary work structure a differential treatment that 
is not entirely predictable, but can often be managed by migrants in their daily lives.

\section{Conclusion: Boundaries, Belonging and Transformation}

Salvadoran migrants in Arkansas, their lives permeated by the precariousness of legal exclusion, confronting a personalized small-town social context of stratified Whiteness, are able to find a contingent social belonging and protection. In the inclusion of Latinos as locals, their critical labor at the center of local systems of production is instrumental. They form the crucial base of local economy and the engine for revitalization, in spite of contestations about the validity of their presence and legitimacy of their labor within broader discourses. Yet this belonging is not only predicated on the material dependency of the economy, but also on the ways that Latinos skillfully deploy narratives of what it means to be a "hard worker" that produce Latinidad as a site of moral and social worth. Through assertions of themselves as ideal workers, migrants insert themselves within social hierarchies as "better than White trash" and therefore valuable members of local social worlds. Salvadorans in Danville drew on both local discourses of hard work and rugged individualism and the historical association of Salvadoran identity with hard work in Latin American contexts. $^{23}$ The local history of the region shapes particular regimes of moral value and spaces of opportunity within racial and class hierarchy, and Latinos' response both reproduces and transforms these moral and racial cultural fields that discipline appropriate social subjects.

The simultaneity of legal exclusion, social acceptance and labor exploitation may seem contradictory - and in some situations they do came into tension but I argue that in Danville these processes are mutually constitutive. ${ }^{24}$ Through their performance of moral boundary work against categories of social undesirability, Latino migrants are accepted by Anglo elites as a valued part of the social world. Nonetheless, this acceptance is predicated on a process of legal subordination, racialized divisions within the working class and systematic labor exploitation. Local Whites will come to the defense of their migrant neighbors when threatened by White supremacist groups, and quotidian encounters in Danville between most Whites and Latinos are relatively cordial. The placid day-to-day harmony experienced and expressed by many residents of the town, however, is belied by the equally constant reiterations of inequality and the ethnic essentialism defining Latino migrants as "suited for" the working conditions in poultry plants. Those who speak up regarding unsafe conditions or suffer injuries and ask for compensation are frequently dismissed, in all senses of the word.

The construction of moral boundaries distinguishing working class from the poor (as well as from professional classes) is not unique to Latino transnational limited to the way that Elena chose to narrate this incident.
23 The slang term used in Spanish to refer to Salvadorans is guanaco, the name of a South American pack animal.

24 A useful antecedent to conceptualize this conundrum is the case of Africans and AfricanAmericans who were legally subordinated under the condition of slavery. In both antebellum and reconstruction Arkansas, racialized legal categories policed the boundary of 
poor Whites with poor non-Whites, assuring that for all the similarity of their experiences and working lives a hierarchical relation remained (Moneyhon, 1997, 14-15; Bolton, 1998, 136, 140-144). In Linda Frost's (2005) historical study of nationbuilding in the Confederacy, she discusses the mediated construction of the slave as an internal Other for Southern society, as belonging within the nation. In contrast to the Yankee, both racialized and demonized as an external 'other', the subordinated and submissive Black slave was portrayed as a valued and legitimate member of society. migrants - as Lamont's work shows, this is a cultural process that can be recognized in various times and places. As Hartigan argues, racial formation is a cultural process, and it is through ethnography that scholars can access the local particularity as well as the repeating patterns of processes of ethnic differentiation that exist across different sites and historical moments (2005, 258-287). It is critical to theorize this not as attributable to a preexisting ethnic essence or heritage, but as emergent from the discursive construction of difference itself: "I understand these patterns of boundary work not as essentialized individual or national characteristics but as cultural structures, that is, institutionalized cultural repertoires or publicly available categorization systems" (Barth, 1969; see also Hartigan, 2005, 243).

The pressure of "illegality" raises the stakes of this boundary work both materially and socially such that migrants must consistently outperform US-born Americans in their own proclaimed values such as work ethic. Work, one of the key signifiers in American culture (Lamont, 2000, 26; Hartigan, 2010, 21, 36-38), provides the logical symbolic mechanism for the assertion of belonging operating in a racial register. As in many other contexts such as deferral of deportation hearings and citizenship tests (Coutin, 2003a,b), immigrants must perform selves that not only minimally conform to, but actively promote dominant ideologies of US nationalism, work ethics and moral "decency." Not incidentally, such discourses also and simultaneously reify essentialist constructions of Latinidad and foreclose the possibility of a critical class consciousness across racial and ethnic boundaries. In this context, one role for scholarly discourse becomes the disruption of social processes of racial formation, or “destructive analysis” in Handler's words (1985). In Hartigan's terms, "To use culture ... in relation to race involves also engaging with and disrupting popular uses and imaginings of the term that do equate its subjects with static, 'traditional,' and unchanging exotic entities" (2005, 276). In the case of the racializing dynamics around Latino migration in the United States in the twenty-first century, this need to disrupt applies not only to static reifications of Latinidad, but also to racialized and White normative views of Americanness that continue to underly variegated systems of oppression.

When Michèle Lamont interviewed White working men in the United States in the early 1990s, they did not perform significant boundary work in relation to immigrants, being far more concerned with preserving distinctions between themselves and the poor as well as racial boundaries against AfricanAmericans. In fact, some expressed views of immigrants similar to those I found in my study:

... the workers I talked to were not much concerned with immigrants. A few workers described immigrants as good, hardworking, family-oriented people and as solid community members who take care of their houses. (Lamont, 2000, 88) 
Nonetheless, most held negative views of immigrants - though these were not expressed as strong concerns, and were not perceived at the time as linked to other concerns about taxes, crime and healthcare cost (Lamont, 2000, 89-92). Lamont concludes that the common denominator in terms of Whites' boundary work around race and morality centers on the evaluation of work ethic and performance, while "[a] notion of equality based on common dignity as human beings is conspicuously absent" $(2000,94)$. Much has changed since Lamont's study in terms of the symbolic association of migrants, particularly Latinos, with economic insecurity, crime and welfare dependency - but perhaps more fundamental aspects have remained the same. The discourse on migrants as "hardworking" and "good neighbors" survives, and provides a constrained avenue toward belonging. More importantly, readings of moral worthiness continue to police the boundaries of communities; more inclusive frames such as those of human rights, universal labor rights or even a common humanity based on biological or spiritual unity appear to be on the decline in an era of neoliberalism.

The boundary work around identities of Salvadorans and other transnational Latino migrants in the Arkansas River valley, while demonstrating the power of agency in constrained social contexts, do not necessarily exemplify a space of potential resistance to racialization and the disciplining power of neoliberal ideologies. On the contrary, they reveal the power of hegemony and the erosion of possibilities for solidarity. Neoliberalism, while it is often presented as a movement away from regulation, actually entails the increasing decentralization and "outsourcing" of capitalist discipline into private spheres of faith and morality (see Harvey, 2005; Ong, 2006). While negotiating local hierarchies of class and moral worth, Salvadoran workers in Arkansas become active cocreators of the very ideologies that reproduce their exploitation - ideologies of work, morality, ethnic essentialism and class hierarchy.

\section{About the Author}

Miranda Cady Hallett, PhD, is Assistant Professor of Cultural Anthropology at Otterbein University in Westerville, Ohio. Her past research projects include work on El Salvador's “War on Gangs," native nations' land claims in upstate New York and voting rights activism among Salvadoran transnational migrants. She has also participated actively in social justice movements, particularly around refugee issues, prisoner's rights and labor justice. Dr Hallett wrote a chapter based on her Arkansas fieldwork in Latin American Migrations to the Heartland, forthcoming from the University of Illinois Press. She is currently working on ethnographic research within Salvadoran state institutions examining structural shifts and transforming notions of national belonging in the context of massive emigration (E-mail: mhallett@otterbein.edu). 


\section{References}

Agee, J. and W. Evans. 1939. Let Us Now Praise Famous Men. New York: Ballantine Books.

Alexander, M. 2010. The New Jim Crow: Mass Incarceration in the Age of Colorblindness. New York: The New Press.

Arias, A. 2003. Central American Americans: Invisibility, Power, and Representation in the US Latino World. Latino Studies 1(1): 168-187.

Bacon, D. 2008. Illegal People: How Globalization Creates Migration and Criminalizes Immigrants. Boston, MA: Beacon Press.

Bailey, A., R. Wright, A. Mountz and I. Miyares. 2002. (Re) Producing Salvadoran Transnational Geographies. Annals of the Association of American Geographers 92(1): 125-144.

Barth, F. 1969. Introduction. In Ethnic Groups and Boundaries: The Social Organization of Cultural Difference, ed. F. Barth, 9-38. London: Allen \& Urwin.

Bolton, S.C. 1998. Arkansas 1800-1860: Remote and Restless. In Histories of Arkansas, ed. E. West, Fayetteville, NC: University of Arkansas Press.

Bolton, S.C. 1999. Slavery and the Defining of Arkansas. Arkansas Historical Quarterly LVIII(1): 1-23.

Cash, W.J. 1941. The Mind of the South. New York: Random House.

Chávez, L. 2008. The Latino Threat: Constructing Immigrants, Citizens, and the Nation. Stanford, CA: Stanford University Press.

Chávez, L. and R. Gonzales. 2008. Illegality, Belonging, and Claiming Citizenship Among 1.5 Generation Undocumented Immigrants. Paper presented at the annual meetings of the AAA; 19 November, San Francisco, California.

Comaroff, J.L. and J. Comaroff. 2005. Naturing the Nation: Aliens, Apocalypse, and the Postcolonial State. In Sovereign Bodies: Citizens, Migrants, and States in the Postcolonial World, eds. T.B. Hansen and F. Steppatut, 120-147. Princeton, NJ: Princeton University Press.

Coutin, S.B. 2003a. Cultural Logics of Belonging and Movement: Transnationalism, Naturalization, and U.S. Immigration Policies. American Ethnologist 30(4): 508-526.

Coutin, S.B. 2003b. Suspension of Deportation Hearings and Measures Of "Americanness". The Journal of Latin American Anthropology 8(2): 58-95.

Coutin, S.B. 2005. Being En Route. American Anthropologist 10(2): 195-206.

Dávila, A. 2008. Latino Spin: Public Image and the Whitewashing of Race. New York: New York University Press.

De Genova, N.P. 2005. Working the Boundaries: Race, Space, and "Illegality" in Mexican Chicago. Durham, NC: Duke University Press.

Fennelly, K. 2008. Prejudice Towards Immigrants in the Midwest. In New Faces in New Places: The Changing Geography of American Immigration, ed. D. Massey, 151-178. New York: Russell Sage.

Frost, L. 2005. Never One Nation: Freaks, Savages, and Whiteness in U.S. Popular Culture, 1850-1877. Minneapolis, MN: University of Minnesota Press.

Gleeson, S. 2011. They Come Here to Work": Examining Narratives of Immigrant Economic Utility. Paper presented at the Boalt Law School workshop: Towards a More Transformative Vision of Immigration Reform: Navigating the Realms of the Ideal and Non-Ideal; 31 May, Berkeley, California. 
Grey, M. and A. Woodrick. 2005. Latinos Have Revitalized Our Community": Mexican Migration and Anglo Responses in Marshalltown, Iowa. In New Destinations: Mexican Immigration in the United States, eds. V. Zúñiga and R. Hernández-León, 133-154. New York: Russell Sage.

Hamilton, N. and N. Stoltz Chinchilla. 1991. Central American Migration: A Framework for Analysis. Latin American Research Review 26(1): 75-110.

Handler, R. 1985. On Dialogue and Destructive Analysis: Problems in Narrating Nationalism and Ethnicity. Journal of Anthropological Research 41(2): 171-182.

Haney López, I. 1994. The Social Construction of Race: Some Observations on Illusion, Fabrication, and Choice. Harvard Civil Rights and Civil Liberties Law Review 29(1): 1-62.

Hartigan Jr, J. 2005. Odd Tribes: Toward a Cultural Analysis of White People. Durham, NC: Duke University Press.

Hartigan Jr, J. 2010. Race in the 21st Century: Ethnographic Approaches. New York: Oxford University Press.

Harvey, D. 2005. A Brief History of Neoliberalism. Oxford: Oxford University Press.

Hernández-León, R. and V. Zúñiga. 2000. Making Carpet By the Mile: The Emergence of a Mexican Immigrant Community in an Industrial Region of the US Historic South. Social Science Quarterly 81(1): 49-66.

Hiemstra, N. 2010. Immigrant "Illegality" as Neoliberal Governmentality in Leadville, Colorado. Antipode 42(1): 74-102.

Hirschman, C. and D. Massey. 2008. Places and Peoples: The New American Mosaic. In New Faces in New Places: The Changing Geography of American Immigration, ed. D. Massey, 1-21. New York: Russell Sage.

Holmes, S. 2007. Oaxacans Like to Work Bent Over": The Naturalization of Social Suffering Among Berry Farm Workers. International Migration 45(3): 39-66.

Hondagneu-Sotelo, P. 2007. Doméstica: Immigrant Workers Cleaning and Caring in the Shadows of Affluence. Berkeley, CA: University of California Press.

Lamont, M. 2000. The Dignity of Working Men: Morality and the Boundaries of Race, Class, and Immigration. Cambridge, MA: Harvard University Press.

Lamont, M. and M. Fournier. 1992. Introduction. In Cultivating Differences: Symbolic Boundaries and the Making of Inequality, eds. M. Lamont and M. Fournier. Chicago, IL: University of Chicago Press.

Lamont, M. and V. Molnár. 2002. The Study of Boundaries in the Social Sciences. Annual Review of Sociology 28: 167-195.

Loewen, J. 1971. The Mississippi Chinese: Between Black and White. Cambridge, MA: Harvard University Press.

Moneyhon, C.H. 1997. Arkansas in the New South: 1874-1929. In Histories of Arkansas, ed. E. West. Fayetteville, NC: University of Arkansas Press.

Motomura, H. 2008. Immigration Outside the Law. Columbia Law Review 108(8): 2037-2097.

Nelson, L. and N. Hiemstra. 2008. Latino Immigrants and the Renegotiation of Place and Belonging in Small Town America. Social and Cultural Geography 9(3): 319-342.

Ngai, M. 2004. Impossible Subjects: Illegal Aliens and the Making of Modern America, Politics and Society in Twentieth-Century America. Princeton, NJ: Princeton University Press.

Ollinger, M., S.V. Nguyen, D. Blayney, B. Chambers and K. Nelson. 2005. Structural Change in the Meat, Poultry, Dairy, and Grain Processing Industries. US Department of Agriculture: Economic Research Service. 
Omi, M. and H. Winant. 1994. Racial Formation in the United States: From the 1960s to the 1990s, 2nd edn. New York: Routledge.

Ong, A. 2006. Neoliberalism as Exception. Durham, NC: Duke University Press.

Randolph, V. 1931. The Ozarks: American Survival of a Primitive Society. New York: The Vanguard Press.

Rodríguez, N. 1987. Undocumented Central Americans in Houston: Diverse Populations. International Migration Review 21(1): 4-25.

Rodríguez, N. 2007. Mexican and Central Americans in the Present Wave of U.S. Immigration. In The Other Latinos: Central and South Americans in the United States, eds. J.L. Falconi and J.A. Mazzoti, 81-100. Cambridge, MA: Harvard University Press.

Romero, R. 2011. Transnational Chinese Immigrant Smuggling to the United States via Mexico and Cuba, 1882-1940. Paper presented at the Law and Society Association Annual Meeting: Oceans Apart? Narratives of (Il)Legality in Liminal Spaces; 2-5 June, San Francisco, California.

Sadowski-Smith, C. 2009. Unskilled Labor Migration and the Illegality Spiral: Chinese, European, and Mexican Indocumentados in the United States, 1882-2007. In Nation and Migration: Past and Future, eds. D.G. Gutierrez and P. Hondagneu-Sotelo, 277-302. Baltimore, MD: The Johns Hopkins University Press.

Sayer, A. 2006. Approaching Moral Economy. In The Moralization of Markets, eds. N. Stehr, C. Henning and B. Weiler, 77-97. New Brunswick, NJ: Transaction Publishers.

Spickard, P. 2007. Almost All Aliens: Immigration, Race, and Colonialism in American History and Identity. New York: Routledge.

Stephen, L. 2007. Transborder Lives: Indigenous Oaxacans in Mexico, California, and Oregon. Durham, NC: Duke University Press.

Stull, D. and M. Broadway. 2008. Meatpacking and Mexicans on the High Plains: From Minority to Majority in Garden City, Kansas. In Immigrants Outside Megalopolis, ed. R. Jones Lanham, MD: Lexington Books.

Valenzuela, A. and B. Fussell. 2011. Construction Work in Post-Katrina New Orleans: Race and Immigration Status. Paper presented at the Law and Society Association Annual Meeting: Oceans Apart? Narratives of (Il)Legality in Liminal Spaces; 2-5 June, San Francisco, California.

Wacquant, L. 2009. Punishing the Poor: The Neoliberal Government of Social Insecurity. Durham, NC: Duke University Press.

Weaver, V. 2007. Frontlash: Race and the Development of Punitive Crime Policy. Studies in American Political Development 21(2): 230-265.

Willen, S. 2007. Exploring "Illegal” and "Irregular" Migrants' Lived Experiences of Law and State Power. International Migration 45(3): 2-7.

Winders, J. 2003. White in All the Wrong Places: White Rural Poverty in the Posbellum U.S. South. Cultural Geographies 10(1): 45-63.

Winders, J. 2005. Changing Politics of Race and Region: Latino migration to the US South. Progress in Human Geography 29(6): 683-699.

Winders, J. 2008. Nashville's New "Sonido": Latino Migration and the Changing Politics of Race. In New Faces in New Places: The Changing Geography of American Immigration, ed. D. Massey, 249-273. New York: Russell Sage.

Wray, M. 2006. Not Quite White: White Trash and the Boundaries of Whiteness. Durham, NC: Duke University Press. 